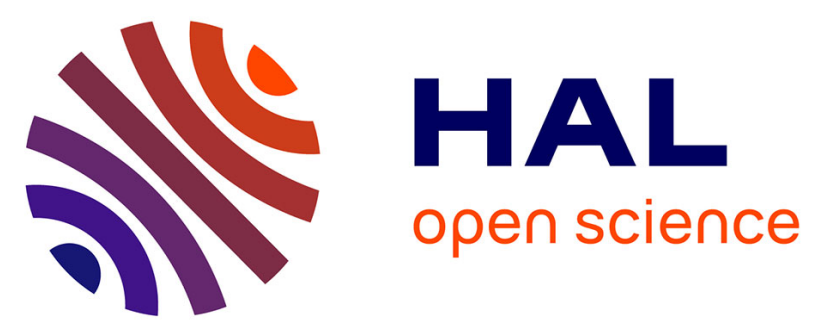

\title{
Homologous growth hormone (GH) binding in gilthead sea bream (Sparus aurata). Effect of fasting and refeeding on hepatic GH binding and plasma somatomedin-like immunoreactivity
}

\author{
J. Perez-Sanchez, H. Marti-Palanca, Pierre-Yves Le Bail
}

\section{To cite this version:}

J. Perez-Sanchez, H. Marti-Palanca, Pierre-Yves Le Bail. Homologous growth hormone (GH) binding in gilthead sea bream (Sparus aurata). Effect of fasting and refeeding on hepatic GH binding and plasma somatomedin-like immunoreactivity. Journal of Fish Biology, 1994, 44, pp.287-301. 10.1006/jfbi.1994.1027 . hal-02714770

\author{
HAL Id: hal-02714770 \\ https://hal.inrae.fr/hal-02714770
}

Submitted on 1 Jun 2020

HAL is a multi-disciplinary open access archive for the deposit and dissemination of scientific research documents, whether they are published or not. The documents may come from teaching and research institutions in France or abroad, or from public or private research centers.
L'archive ouverte pluridisciplinaire HAL, est destinée au dépôt et à la diffusion de documents scientifiques de niveau recherche, publiés ou non, émanant des établissements d'enseignement et de recherche français ou étrangers, des laboratoires publics ou privés. 


\title{
Homologous growth hormone (GH) binding in gilthead sea bream (Sparus aurata). Effect of fasting and refeeding on hepatic GH-binding and plasma somatomedin-like immunoreactivity
}

\author{
J. Pérez-Sánchez*, H. Martí-Palanca* and P-Y. Le Bail $†$ \\ *Instituto de Acuicultura de Torre de la Sal, CSIC, 12595 Torre de la Sal, Ribera de \\ Cabanes, Castellón, Spain and †Laboratoire de Physiologie des Poissons, INRA, \\ Campus de Beaulieu, 35042 Rennes Cedex, France
}

(Received 9 September 1992, Accepted 10 April 1993)

\begin{abstract}
Specific binding of gilthead sea bream growth hormone (sbGH) to liver membrane preparations was a time and temperature dependent process, and was saturable by increasing amounts of membrane proteins. Scatchard analysis evidenced a single class of high-affinity and lowcapacity binding sites. Ovine prolactin, recombinant tilapia prolactin, carp gonadotropin and chinook salmon gonadotropin did not compete for the ${ }^{125} \mathrm{I}-\mathrm{sbGH}$ binding sites, while recombinant trout $\mathrm{GH}$, bovine $\mathrm{GH}$ and human $\mathrm{GH}$ displaced iodinated sbGH in a dose dependent-manner. IGF-I-like immunoreactivity was detected after acidification of plasma and removal of IGF-I binding activity. A parallel displacement to the rhIGF-I standard was observed with extracted plasma samples. Free and total hepatic GH-binding decreased during long-term starvation (3-9 weeks), returning to control values during the refeeding period. Plasma IGF-I-like immunoreactivity showed a similar trend. To our knowledge, this is the first report that indicates a coordinated regulation of GH-binding and plasma somatomedin-like activity in a typical marine fish.
\end{abstract}

Key words: growth hormone; insulin-like growth factors; fasting; gilthead sea bream; teleost.

\section{INTRODUCTION}

The importance of growth hormone (GH) in supporting animal growth has been known for a long time. The original concept implies that GH stimulates the systemic release from the liver of insulin-like growth factor-I (IGF-I) which, in turn, stimulates bone growth (Salmon \& Daughaday, 1957). In addition, GH induces the production of IGF-I in many tissues other than liver, initiating local growth by paracrine or autocrine mechanisms (Holly \& Wass, 1989). A further complication is that IGFs are bound to specific carrier proteins, which exert an important modulatory action on systemic and local IGF activity (Baxter, 1988). All this has been defined primarily in mammalian systems, but there is evidence supporting a physiological role of IGFs on the growth-promoting effect of GH in other vertebrates.

In fish, several reports indicate that the liver is the most important target tissue for the direct action of GH (Fryer, 1979; Gray et al., 1990; Hirano, 1991; Yao et al., 1991; Sakamoto \& Hirano, 1991; $\mathrm{Ng}$ et al., 1992). GH treatment increases hepatic IGF-I mRNA (Cao et al., 1989) and serum IGF-I immunoreactivity (Funkenstein et al., 1989; $\mathrm{Ng}$ et al., 1991). A close relationship between GH 
pulses and plasma IGF-I-like immunoreactivity has been observed in rainbow trout Oncorhynchus mykiss Walbaum (Niu et al., 1993). In addition, it has been demonstrated that human IGF-I inhibits basal GH secretion by pituitary cells of rainbow trout (Pérez-Sánchez et al., 1992), delineating the participation of somatomedins on the negative feedback loop of GH release. Further studies indicate that IGFs mediate the stimulatory action of GH on the sulphate uptake by trout (Komourdjian \& Idler, 1978) and Japanese eel Anguilla japonica Sohlegel (Duan \& Hirano, 1990; Duan \& Inui, 1990) cartilage. Recent studies in long-jawed mudsucker Gillichthys mirabilis Cooper (Gray \& Kelley, 1991) and coho salmon Oncorhynchus kisutch Walbaum (McCormick et al., 1992) indicate that short-term inanition decreases this sulphate uptake, which is enhanced by bovine IGF-I. Moreover, it has been demonstrated that long-term fasting reduces not only hepatic IGF-I mRNA but also hepatic GH-binding in Japanese eel (Duan \& Hirano, 1992) and coho salmon (Gray et al., 1992), respectively. The aim of this work was to examine the co-ordinate regulation of GH-binding and plasma IGF-I activity in a typical marine fish, such as gilthead sea bream Sparus aurata L., which is successfully cultured in the Mediterranean area. For this purpose, we have developed a homologous GH radioreceptor assay and validated a double antibody-radioimmunoassay for human IGF-I.

\section{MATERIALS AND METHODS}

\section{HORMONES AND REAGENTS}

Gilthead sea bream GH (sbGH) was purified from pituitary extracts according to the isolation procedure used for chinook salmon Oncorhynchus tshawytscha Walbaum GH (sGH) (Le Bail et al., 1989). Electrophoretic characterization of sbGH evidenced two major bands which corresponded to the monomeric forms of sGH. Rabbit antibodies against sbGH immunostained somatotrope cells of the proximal pars distalis of gilthead sea bream pituitary (Le Bail et al., 1993). Recombinant human IGF-I (rhIGF-I) was kindly provided by Dr K. Müller (Ciba-Geigy, Basel, Switzerland). The rabbit antiserum (UB3-189) against human IGF-I was prepared by L. Underwood and J. J. Van Wyk (University of North Carolina at Chapel Hill, Chapel Hill, NC, U.S.A.) and made available through the National Hormone and Pituitary Distribution Program (Baltimore, MD, U.S.A.). This rabbit antiserum does not show appreciable cross-reaction with insulin and IGF-II. Human GH (hGH), bovine GH (bGH) and ovine prolactin (oPRL) were obtained from the National Hormone and Pituitary Distribution Program. Chinook salmon gonadotropin (sGtH) and carp Cyprinus carpio L. gonadotropin (cGtH) were generously provided by Dr B. Breton (Laboratoire Physiologie des Poissons, Rennes, France). Recombinant tilapia Oreochromis sp. prolactin (rtiPRL) and recombinant trout $\mathrm{GH}(\mathrm{rtGH})$ were generously provided by Dr J. Smal (Eurogentec, Liège, Belgium).

\section{IODINATION}

sbGH and rhIGF-I were iodinated by the chloramine $\mathrm{T}$ method (Greenwood et al., 1963) with Martal's (1972) modification. Unreacted iodide was separated from labelled proteins by gel filtration in a Sephadex G-25 column (PD10, Pharmacia). Both ${ }^{125}$ I-sbGH and ${ }^{125}$ I-rhIGF-I were stable for about 2 months, stored in glycerol (1:1) at $-20^{\circ} \mathrm{C}$. 


\section{MEMBRANE PREPARATION}

Liver, brain, muscle and visceral fat tissues were placed in ice-cold extraction buffer ( $20 \mathrm{~mm}$ Tris- $\mathrm{HCl}, 5 \mathrm{mM} \mathrm{MgCl}, 0 \cdot 1 \%$ sodium azide, $\mathrm{pH}=7 \cdot 5$ ). Each tissue was homogenized using a Polytron homogenizer. The homogenate was passed through a cheesecloth and was further homogenized with a glass Teflon homogenizer. The final homogenate was centrifuged at $3000 \mathrm{~g}$ for $15 \mathrm{~min}$. The pellet was suspended with the extraction buffer and centrifuged again at $3000 \mathrm{~g}$. The pellet was kept to test its $\mathrm{GH}$ binding. Protein concentration was determined by a Bio-Rad protein assay kit, using bovine serum albumin (BSA) as standard.

\section{DISSOCIATION PROCEDURE AND GH-BINDING ASSAY}

To determine total binding sites, bound $\mathrm{GH}$ was dissociated from its receptor by exposing membranes to $4 \mathrm{M} \mathrm{MgCl}_{2}$ as described by Kelly et al. (1979) and Maiter et al. (1988). Free binding sites were determined with untreated membrane preparations. To verify that $4 \mathrm{M} \mathrm{MgCl}_{2}$ treatment for $10 \mathrm{~min}$ was efficient for the removal of endogeneous $\mathrm{GH}$, hepatic membranes from gilthead sea bream were saturated with unlabelled sbGH ( $200 \mathrm{ng} \mathrm{ml}^{-1}$ or $50 \mathrm{ng} \mathrm{ml}^{-1}$ ). The $3000 \mathrm{~g}$ pellet from these membranes was then treated with $\mathrm{MgCl}_{2}$ and tested for binding of ${ }^{125} \mathrm{I}-\mathrm{sbGH}$. The decrease in specific binding following preincubation with sbGH was restored by the dissociation procedure (Table I).

For binding studies, membrane preparations and labelled sbGH in assay buffer containing $0.5 \% \mathrm{BSA}, 0.25 \mathrm{mg} \mathrm{m} \mathrm{m}^{-1}$ of trypsin inhibitor and $0.5 \mathrm{~mm}$ ascorbic acid were incubated for $14 \mathrm{~h}$ at $15^{\circ} \mathrm{C}$ in a final volume of $300 \mu \mathrm{l}$. The assay was terminated by adding $3 \mathrm{ml}$ ice-cold extracted buffer. Bound and free radioactivity were separated by centrifugation ( $3000 \mathrm{~g}$ for $15 \mathrm{~min}$ ) and the pellets were counted in a Packard gamma counter. Total binding was measured in the absence of unlabelled hormone and non-specific binding was taken as the ${ }^{125} \mathrm{I}$ remaining in the presence of $2 \mu \mathrm{g}$ unlabelled rtGH. Specific binding was determined by subtracting the non-specific binding from the total binding.

\section{IGF-I RADIOIMMUNOASSAY}

Anti-human IGF-I serum $(100 \mu$ l) diluted $(1: 2500)$ in RIA buffer $(50 \mathrm{~mm}$ Tris-HCl $\mathrm{pH}=7 \cdot 5$, containing $10 \mathrm{mM} \mathrm{MgCl} 2,0 \cdot 05 \%$ sodium azide, $0 \cdot 1 \%$ Triton X-100 and $1 \%$ BSA) was added to $100 \mu \mathrm{l}$ plasma aliquots after each acid treatment and dilution, which is described later. After $24 \mathrm{~h}$ of incubation at room temperature, $100 \mu \mathrm{l}$ of buffered rhIGF-1 $(15000 \mathrm{cpm})$ were added to each tube and incubation continued for $24 \mathrm{~h}$. Precipitation of the antibody-bound peptide was made by addition of $100 \mu \mathrm{l}$ of diluted serum of goat anti-rabbit $\gamma$ globulin in $50 \mathrm{~mm}$ Tris- $\mathrm{HCl}(\mathrm{pH}=7.5)$, containing $10 \mathrm{~mm}$ $\mathrm{MgCl}_{2}, 0.05 \%$ sodium azide and $7.5 \%$ polyethylene glycol. The incubation was prolonged for $24 \mathrm{~h}$ at room temperature and the assay was terminated by adding $3 \mathrm{ml}$ of $50 \mathrm{mM}$ Tris- $\mathrm{HCl}(\mathrm{pH}=7.5)$, containing $10 \mathrm{mM} \mathrm{MgCl}_{2}$ and $0.05 \%$ sodium azide. The tubes were then centrifuged for $45 \mathrm{~min}$ at $3000 \mathrm{~g}$. The supernatant was decanted and the radioactivity in the bound fraction was determined in a gamma counter. A significant displacement of ${ }^{125} \mathrm{I}$-labelled rhIGF-I occurred at $30 \mathrm{pg}$ ligand with $1 \%$ non-specific binding and $40 \%$ of specific bound count at zero dose/total count.

\section{ACID GEL FILTRATION}

The extraction was performed according to the procedure of Zapf et al. (1980). Plasma samples of $1 \mathrm{ml}$ were acidified with acetic acid to a final concentration of $0.5 \mathrm{M}$ and incubated for $1 \mathrm{~h}$ at $4^{\circ} \mathrm{C}$ to dissociate IGFs from IGF-binding proteins. The acidified plasma was then chromatographed on Sephadex G-75 using a glass column $(7 \times 500 \mathrm{~mm})$, calibrated before use with dextran blue, albumin, ovalbumin, chymotrypsinogen $A$ and labelled rhIGF-I. The samples were eluted with $1 \mathrm{~m}$ acetic acid containing $150 \mathrm{~mm} \mathrm{NaCl}$ and $0.1 \% \mathrm{BSA}$ at a flow rate of $8 \mathrm{~m} / \mathrm{h}$. Fractions of $300 \mu \mathrm{l}$ were collected and neutralized $(1: 5)$ with Tris base $(200 \mathrm{~mm}, \mathrm{pH}=9)$. The supernatant was diluted in RIA buffer before further assays. 
TABLE I. Dissociation of sbGH bound to liver binding sites of gilthead sea bream and rebinding of ${ }^{125} \mathrm{I}$-sbGH

\begin{tabular}{lccc}
\hline \multirow{2}{*}{ Preincubation } & Treatment & \multicolumn{2}{c}{${ }^{125} \mathrm{I}-\mathrm{sbGH}$ specific binding } \\
\cline { 3 - 4 } & & $\mathrm{B} / \mathrm{T} \times 100$ & Percentage of control \\
\hline Assay buffer (control) & Untreated & $14 \cdot 1 \pm 0.5$ & 100 \\
Assay buffer & $4 \mathrm{M} \mathrm{MgCl}_{2}$ & $18 \cdot 2 \pm 0 \cdot 8$ & 129 \\
+ sbGH $\left(50 \mathrm{ng} \mathrm{ml}^{-1}\right)$ & Untreated & $4 \cdot 2 \pm 0.3$ & $29 \cdot 7$ \\
+ sbGH $\left(50 \mathrm{ng} \mathrm{ml}^{-1}\right)$ & $4 \mathrm{M} \mathrm{MgCl}_{2}$ & $17 \cdot 2 \pm 1.5$ & 121.9 \\
+ sbGH $\left(200 \mathrm{ng} \mathrm{ml}^{-1}\right)$ & Untreated $^{-1}$ & 0 & 0 \\
+ sbGH $\left(200 \mathrm{ng} \mathrm{ml}^{-1}\right)$ & $4 \mathrm{MgCl}_{2}$ & $18.4 \pm 0.9$ & 130.9 \\
\hline
\end{tabular}

Note, values are expressed as mean \pm S.E.M. $(n=3)$. The specific binding is shown as a percentage of the total radioactivity bound to $200 \mu \mathrm{g}$ of membrane proteins.

\section{SEPHADEX CM-25 EXTRACTION}

Plasma samples of $250 \mu \mathrm{l}$ were acidified with $250 \mu \mathrm{l}$ of $1 \mathrm{M}$ acetic acid containing $150 \mathrm{mM} \mathrm{NaCl}$ and incubated for $1 \mathrm{~h}$ at $4^{\circ} \mathrm{C}$. IGFs were then extracted according to the procedure of Niu et al. (1993). Briefly, $500 \mu \mathrm{l}$ of Sephadex CM-25 in acetic acid solution $(1: 1, \mathrm{v} / \mathrm{v})$ were added to acidified plasma. The tubes were incubated for $30 \mathrm{~min}$ at room temperature and the supernatant was decanted after centrifugation at $3000 \mathrm{~g}$ for $15 \mathrm{~min}$. The precipitate was incubated with $2 \mathrm{ml}$ of $10 \mathrm{~mm}$ acetic acid $(\mathrm{pH}=3)$ for $30 \mathrm{~min}$ at room temperature to remove IGF carrier proteins. The tubes were centrifuged and the precipitate washed three times $(750 \mu \mathrm{l})$ in Tris base $(200 \mathrm{~mm}, \mathrm{pH}=9)$. The supernatants were then pooled and diluted in RIA buffer before further assays.

\section{FASTING}

In order to determine the effects of long-term fasting on GH-binding and plasma IGF-I immunoreactivity, two groups $(n=70)$ of 1 -yr-old gilthead sea bream were acclimated in separate 500-1 fibreglass tanks for a period of 3 weeks. Following the acclimation period, food was withheld for one group during 9 weeks with a subsequent 2-week period of refeeding. At 0, 7, 21, 63 and 77 days after the beginning of the experiment, 10 animals from fed and fasted fish were sampled. Blood was collected from the caudal vessels into heparinized tubes and centrifuged at $3000 \mathrm{~g}$ for $20 \mathrm{~min}$; plasma was stored at $-40^{\circ} \mathrm{C}$ until analysis. Liver membranes were immediately prepared and stored at $-40^{\circ} \mathrm{C}$ in the extraction buffer diluted in glycerol (1:1). Just before use, the frozen suspensions were washed and diluted with assay buffer to appropriate concentration.

\section{STATISTICS}

B/Bo values derived from serial dilutions of hormone preparations and plasma samples were converted to logits; the slopes were calculated for each set of points and then compared to sbGH or rhIGF-I standard curve by analysis of covariance. The slopes were considered to be significantly different if $P<0 \cdot 05$. One-way analysis of variance followed by Duncan's multiple range-test was used to evaluate differences between fed and fasted groups during each sampling time, as well as within each group over time.

\section{RESULTS}

GH binding to liver membrane preparations was time and temperaturedependent (Fig. 1). At $4^{\circ} \mathrm{C}$, the specific binding of labelled sbGH to $250 \mu \mathrm{g}$ of 


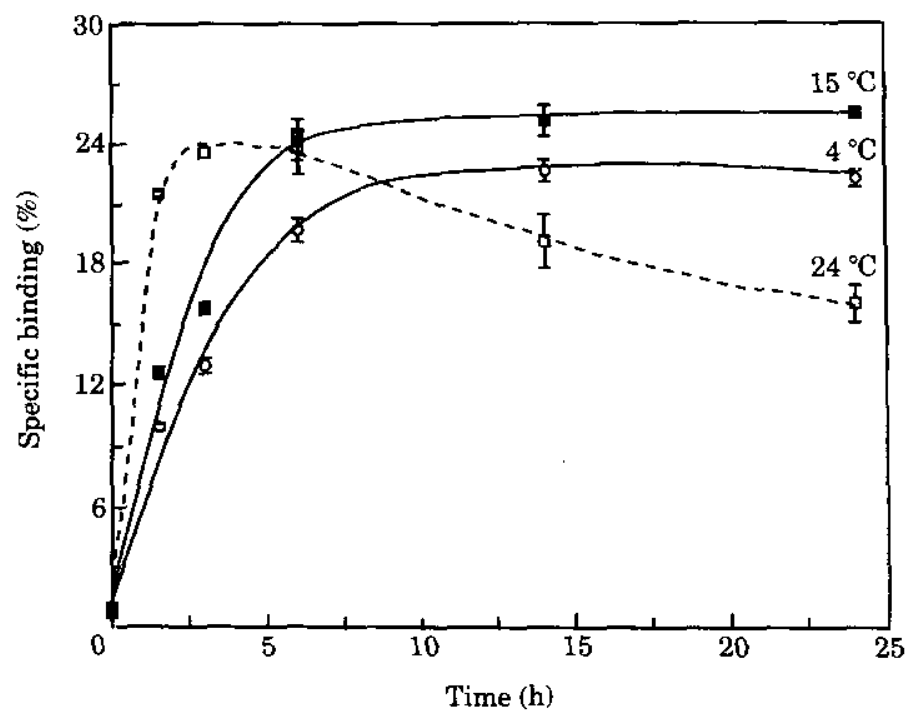

FIG. 1. Effect of time and temperature on specific binding of ${ }^{125} \mathrm{I}$-sbGH $(24000 \mathrm{cpm})$ to gilthead sea bream liver membranes. Each point represents the mean \pm s.E.M. of triplicate determinations.

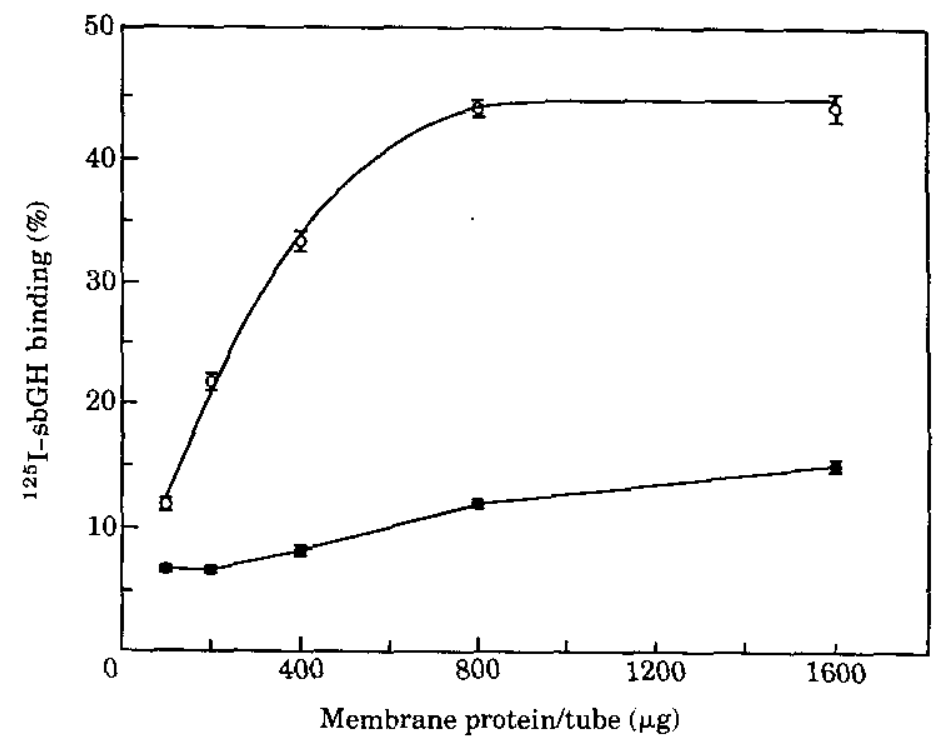

FIG. 2. Effect of the amount of liver membrane proteins on specific $(O)$ and non-specific ( $\square$ ) binding of ${ }^{125} \mathrm{I}-\mathrm{sbGH}(25000 \mathrm{cpm})$. Each point represents the mean \pm S.E.M. of triplicate determinations.

membrane proteins increased from $10 \%$ after $1.5 \mathrm{~h}$ to $22 \%$ after $14 \mathrm{~h}$, when it appeared to reach equilibrium. At $15^{\circ} \mathrm{C}$, the specific binding increased from $12 \%$ after $1.5 \mathrm{~h}$ to $24 \%$ after $6 \mathrm{~h}$, and then reached a steady state (14-24 h). At $24^{\circ} \mathrm{C}$, the specific binding was at maximum $(22 \%)$ after $3 \mathrm{~h}$, but it declined gradually after $6 \mathrm{~h}$ of incubation. Thus, further assays were performed at $15^{\circ} \mathrm{C}$ for $15-20 \mathrm{~h}$. 


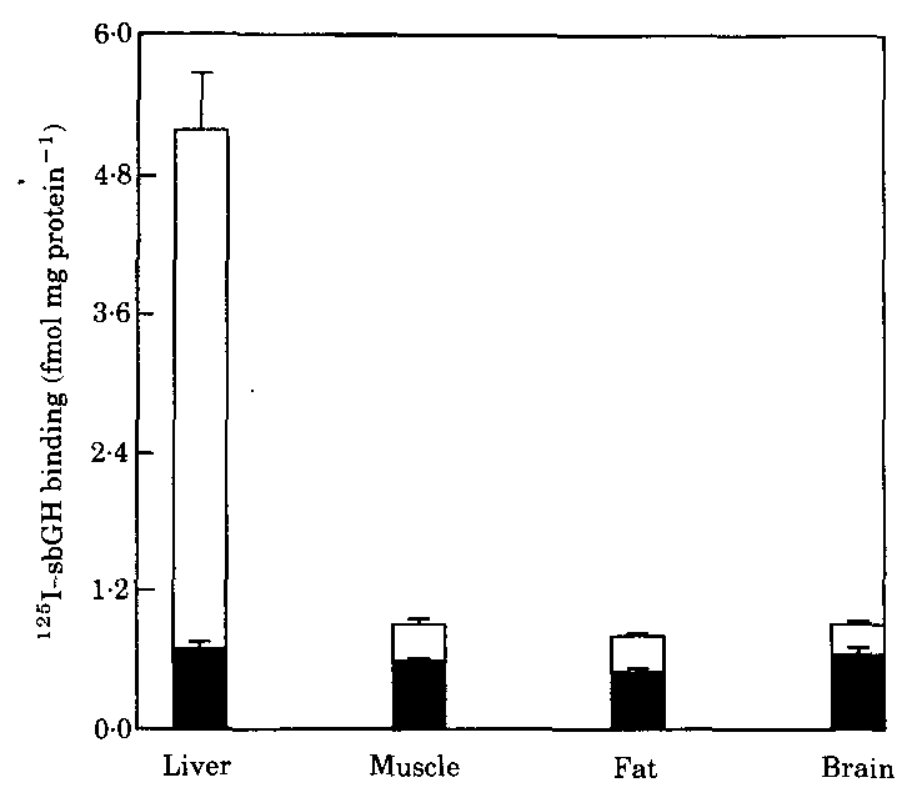

Fig. 3. Total ( $\square$ ) and non-specific ( $\mathbf{\square})$ binding of ${ }^{125} \mathrm{I}$-sbGH $(30000 \mathrm{cpm}$ ) to membranes from gilthead sea bream organs. Each histogram represents the mean \pm S.E.M. of five determinations.

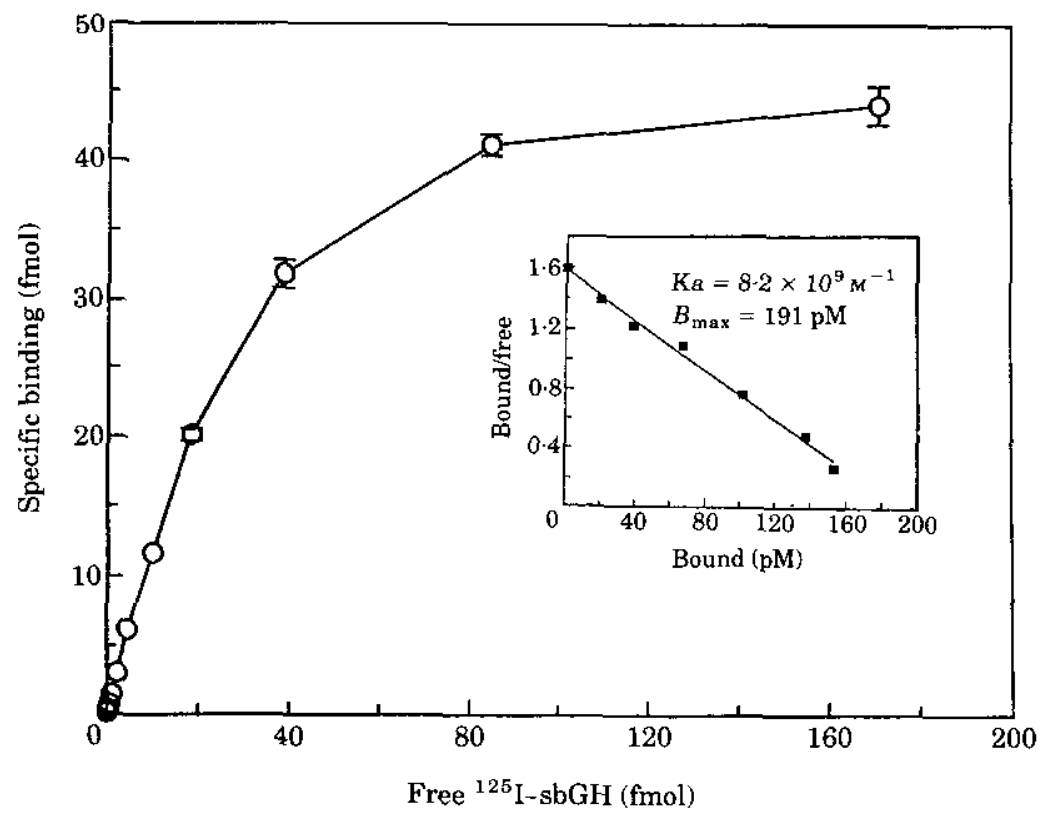

FIG. 4. Saturable specific binding of ${ }^{125} \mathrm{I}$-sbGH to gilthead sea bream liver membrane proteins $(250 \mu \mathrm{g})$. Each point represents the mean \pm s.E.M. of triplicate determinations. The insert represents the derived Scatchard plot.

The specific binding of ${ }^{125} \mathrm{I}$-sbGH increased with the amount of membrane proteins added, achieving a plateau that demonstrated that up to $45 \%$ of iodinated sbGH can be specifically bound to somatogenic binding sites (Fig. 2). 
TABLE II. Binding affinity $(\mathrm{Ka})$ and binding capacity $\left(B_{\max }\right)$ of treated $\left(\mathrm{MgCl}_{2}\right)$ and untreated liver membrane preparations

\begin{tabular}{|c|c|c|}
\hline & $\mathrm{Ka}\left(\mathrm{M}^{-1}\right)$ & $B_{\max }\left(\right.$ fmol mg protein $\left.{ }^{-1}\right)$ \\
\hline $\begin{array}{l}\text { Untreated } \\
4 \mathrm{M} \mathrm{MgCl}_{2}\end{array}$ & $\begin{array}{l}6 \cdot 8 \pm 0.7 \times 10^{9} \\
7 \cdot 1 \pm 1 \cdot 1 \times 10^{9}\end{array}$ & $\begin{array}{l}150 \cdot 5 \pm 15 \cdot 3 \\
195 \cdot 8 \pm 20 \cdot 2\end{array}$ \\
\hline
\end{tabular}

Note, values are expressed as mean \pm S.E.M. of three-four separate determinations.

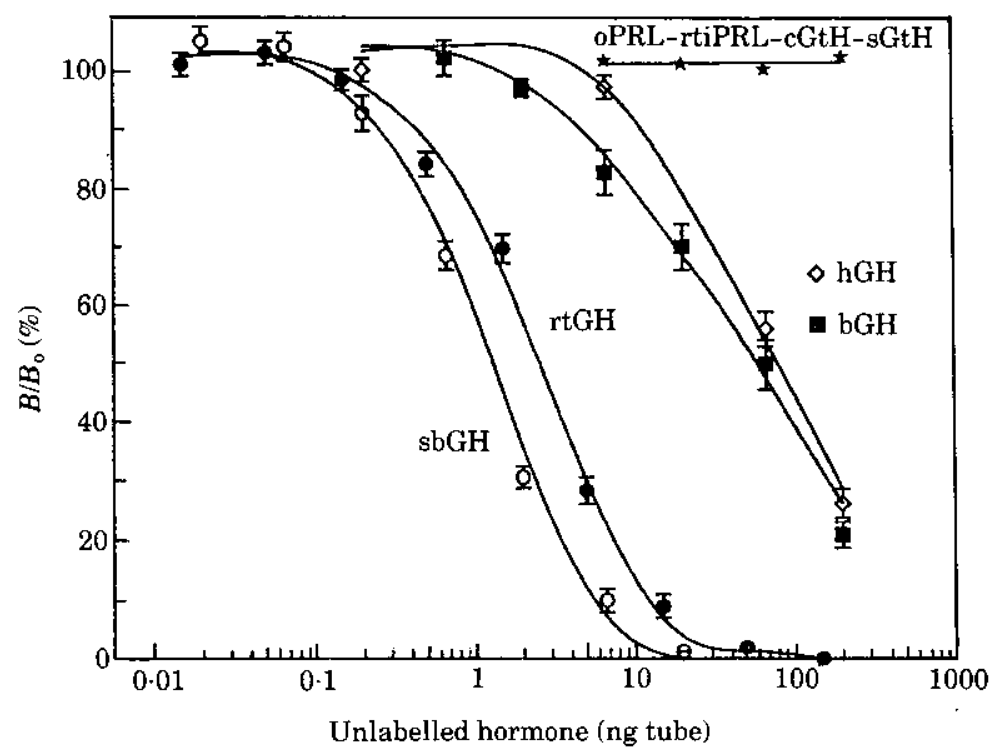

FIG. 5. Competitive displacement of ${ }^{125} \mathrm{I}-\mathrm{sbGH}(30000 \mathrm{cpm})$ from gilthead sea bream liver membrane proteins $(100 \mu \mathrm{g})$. Gilthead sea bream (sbGH); recombinant trout $\mathrm{GH}(\mathrm{rtGH})$; human $\mathrm{GH}(\mathrm{hGH})$; bovine GH (bGH); ovine prolactin (oPRL); recombinant tilapia prolactin (rtiPRL); carp gonadotropin $(\mathrm{cGtH})$; chinook salmon gonadotropin $(\mathrm{sGtH})$. Each value represents the mean \pm S.E.M. of four replicates.

The non-specific binding ranged between 7 and $15 \%$ of total counts added. Appreciable binding was detected in brain, muscle and visceral fat membrane preparations. However, the amount of specific binding was markedly lower than in liver ones (Fig. 3).

Scatchard analyses were carried out by incubating a fixed amount of liver membranes with increased amounts of labelled sbGH (Fig. 4). Scatchard plots were always linear, denoting the presence of a single class of high affinity and low capacity binding sites. Table II summarizes sbGH-binding characteristics in treated $\left(\mathrm{MgCl}_{2}\right)$ and untreated membrane preparations.

Competitive studies were performed incubating liver membranes with a fixed amount of iodinated sbGH and increasing amounts of unlabelled hormone preparations (Fig. 5). oPRL, rtiPRL, cGtH and sGtH did not displace ${ }^{125} \mathrm{I}-$ $\mathrm{sbGH}$ from the binding sites at any of the concentrations tested. hGH and bGH displaced iodinated sbGH in a dose dependent-manner, though the inhibitory 


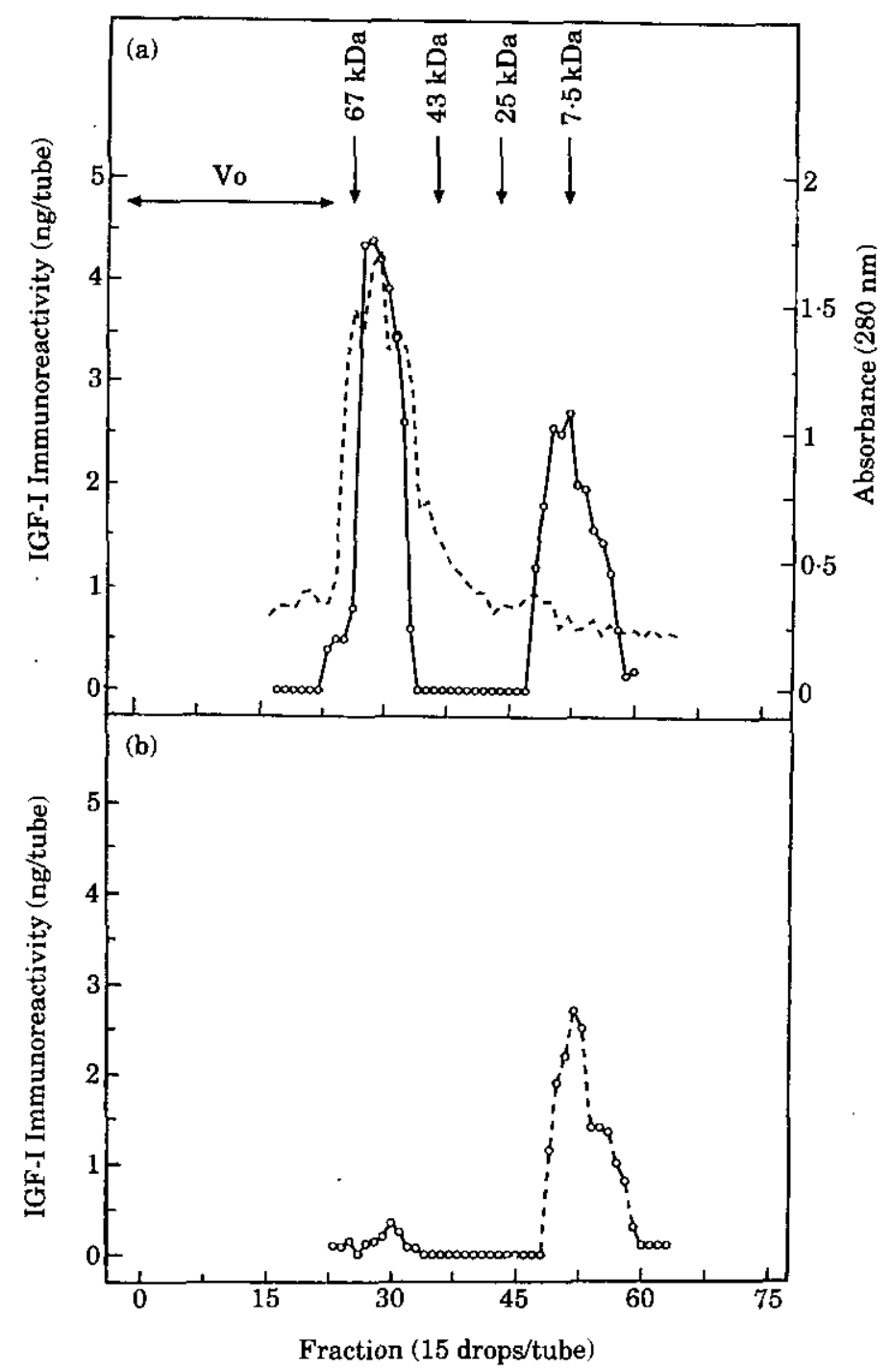

Frg. 6. Acid gel filtration of gilthead sea bream plasma on Sephadex G-75 column before (a) and after CM-25 extraction (b). The column effluent was monitored by IGF-I immunoreactivity (-O-). The protein profile was plotted on the same graph as optical density (--). Vo, Void volume. Arrows indicate molecular weight markers, including albumin (67 kDa), ovalbumin (43 kDa), chymotrypsinogen A ( $25 \mathrm{kDa})$ and ${ }^{125} \mathrm{I}$-rhIGF-I (7.5 kDa).

potency appear to be $20-40$-fold lower than that of sbGH. In contrast, the inhibitory potency of rtGH was two-fold lower than that of sbGH.

The chromatographic profile of gilthead sea bream plasma following acidification and separation over a Sephadex G-75 column is shown in Fig. 6(a). Two immunoreactive peaks were detected by IGF-I RIA. Peak I showed an apparent molecular weight of $50-60 \mathrm{kDa}$. Peak II showed an apparent molecular weight of 7-8 kDa. IGF-I immunoreactivity after Sephadex CM-25 extraction was also characterized. The extract was concentrated in ultrafree-MC filters (Millipore) with a 5000 molecular weight limit, and then chromatographed over a Sephadex 


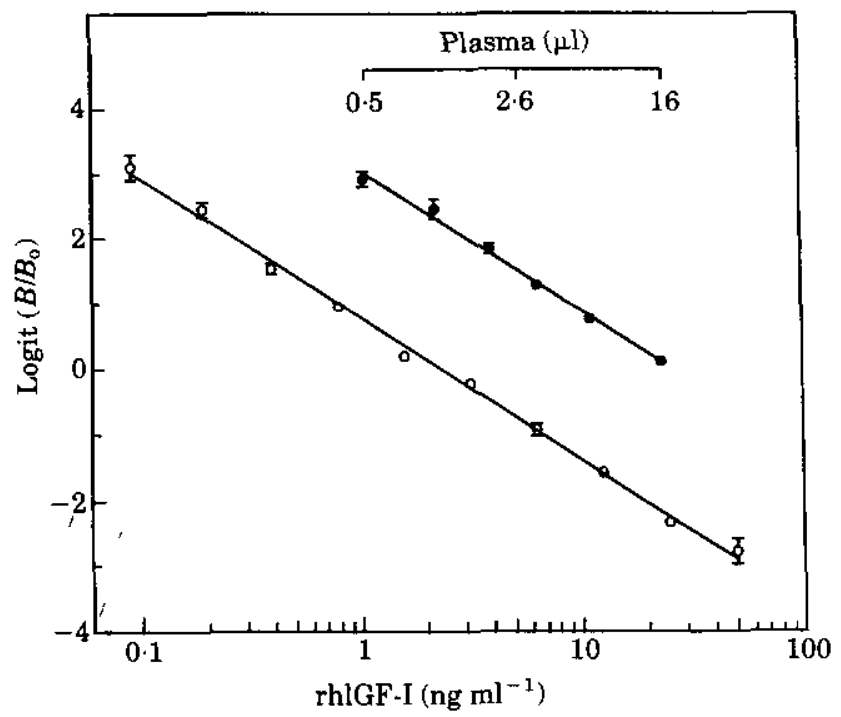

FIG. 7. Parallelism between serial dilutions of gilthead sea bream plasma $(O)$ and rhIGF-I standard $(O)$ measured by radioimmunoassay. Plasma IGF-I-like peptides were extracted by Sephadex CM-25. Each value represents the mean \pm S.E.M. of four replicates.

G-75 column (acid-gel filtration). Peak I was absent, without a significant loss of IGF-I immunoreactivity in the region of the free tracer peak [Fig. 6(b)], whose displacement curve was parallel to the standard curve in the IGF-I radioimmunoassay (Fig. 7). The recovery of rhIGF-I added to non-extracted gilthead sea bream plasma ranged between 85 and $95 \%$.

Figure 8 shows the effect of fasting and refeeding on hepatic GH-binding and plasma IGF-I-like levels (Sephadex CM-25 extract). GH-binding affinity remained unchanged, but a progressive loss in total and free GH-binding was evidenced after 9 weeks of fasting, returning to control values after 2 weeks of refeeding. A similar trend was observed in plasma IGF-I-like immunoreactivity. Interestingly, we also observed that fed fish showed a significant increase of plasma IGF-I-like immunoreactivity in coincidence with the seasonal increase of water temperature and somatic growth. Free GH-binding decreased gradually, while total GH-binding increased significantly in the last sampling time.

\section{DISCUSSION}

The present study demonstrated for the first time in a typical marine fish the presence of specific GH-binding sites with the general characteristics of hormone receptors. As expected, the liver appeared as the main source of GH-binding, corroborating the idea that the liver is an important target tissue for the direct action of GH (Mendelshon, 1988). Of particular significance is the observation that long-term fasting reduced both hepatic GH-binding and plasma IGF-I-like immunoreactivity.

Specific sbGH-binding was dependent on time, temperature and membrane concentration as it has been described for other polypeptide hormones (Cuatrecasas et al., 1977). At $15^{\circ} \mathrm{C}$, specific binding was maximal in $6 \mathrm{~h}$, being 


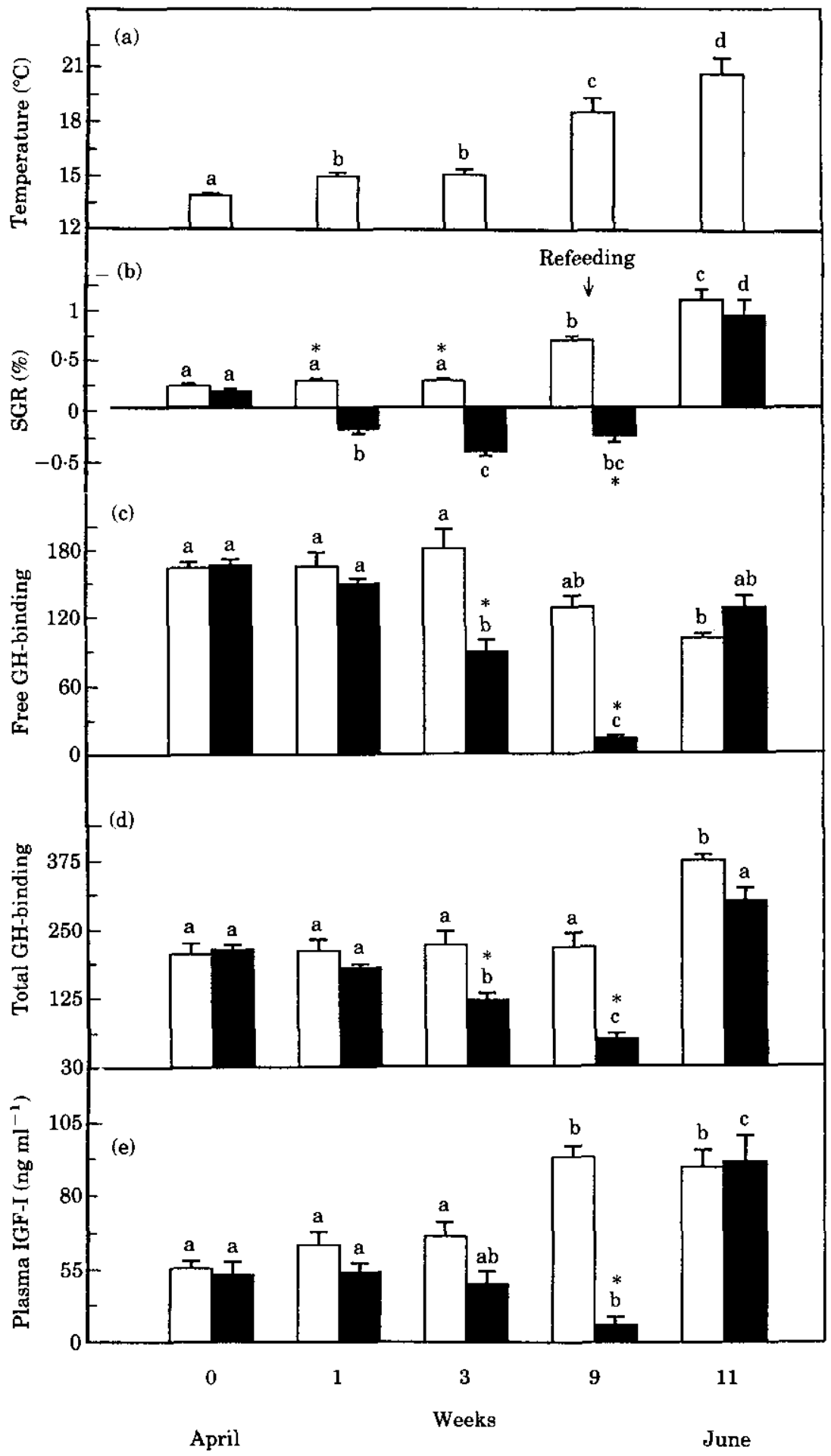


steady at least until $24 \mathrm{~h}$. In contrast, a significant decline in specific binding was observed at $24^{\circ} \mathrm{C}$ after $14 \mathrm{~h}$ of incubation, which could be due to denaturation and/or degradation of ligand and/or receptor protein. A similar phenomenon has been reported in trout (Yao et al., 1991) and eel (Hirano, 1991) GH radioreceptor assays at 20 and $35^{\circ} \mathrm{C}$, respectively. Tarpey \& Nicoll (1985) have also reported a decrease in the specific binding of bovine $\mathrm{GH}$ to long-jawed mudsucker liver membranes $8 \mathrm{~h}$ after incubation at $37^{\circ} \mathrm{C}$.

Scatchard analysis of the binding of iodinated sbGH to gilthead sea bream liver membranes consistently produced a straight-line Scatchard plot, indicating a single class of binding sites. The binding affinity and capacity are in accordance with the values reported for the homologous binding of mammalian (Gerasimo et al., 1979; Hughes, 1979), avian (Leung et al., 1987) and fish (Fryer, 1979; Gray et al., 1990; Hirano, 1991; Yao et al., 1991; Ng et al., 1992) GHs to liver membrane preparations, and appear to conform to the general requirements expected in hormone receptor interactions.

Similarities in primary structure between GHs and PRLs suggest that these hormones have evolved from a common ancestral molecule ( $\mathrm{Li}, 1972)$. In spite of this, both oPRL and rtiPRL did not demonstrate affinity for the sbGHbinding sites. Other pituitary hormones ( $\mathrm{cGtH}$ and sGtH) did not compete with labelled sbGH for binding sites, which is not surprising given the structural and functional differences between GHs and GtHs. Conversely, rtGH, and mammalian GHs were able to displace labelled sbGH bound to hepatic binding sites, though human and bovine GHs exhibited a limited affinity for these somatogenic binding sites, in a similar manner as it has been established in tilapia (Fryer, 1979; Ng et al., 1992) and salmonid (Gray et al., 1990; Yao et al., 1991) GH radioreceptor assays. In contrast, the inhibitory potency of $\mathrm{rtGH}$ was comparable to that of sbGH, which is in agreement with the observation that sbGH shows a high affinity for chinook salmon GH-binding sites (Yao et al., 1991).

Thus far, information concerning IGF activity in gilthead sea bream has been limited to the study of Funkenstein and co-workers (1989). We confirmed that mammalian IGF-I antibodies can be used to detect IGF-I-like immunoreactivity in the plasma of gilthead sea bream. Serum from rainbow trout (Daughaday $e t$ al., 1985), tilapia ( $\mathrm{Ng}$ et al., 1991) and channel catfish Ictalurus punctatus (Rafinesque) (Delahunty et al., 1992) cross-react in mammalian IGF-I RIAs. However, sera from Atlantic blue fish Pomatomus saltatrix (L.) (Furlanetto et al., 1977), Atlantic salmon Salmo salar L. (Lindahl et al., 1985), leopard shark Triakis semifasciata Girarde and carp (Wilson \& Hintz, 1982) do not exhibit significant cross-reactivity. These discrepancies remain unclear, though it could be due to the use of different antibodies. In addition, a suitable dissociation and removal of IGF-binding proteins (IGF-BPs) from circulating IGFs appear to

FIG. 8. Effect of fasting and refeeding on growth parameters. (a) Water temperature. (b) Weight specific growth rates. Each value represents the mean \pm S.E.M. of two backs. (c) Free and (d) total hepatic GH-binding (fmol/mg protein). Each value represents the mean \pm S.E.M. of four to five determinations. (e) Plasma IGF-I-like immunoreactivity. Each value represents the mean \pm S.E.M. of eight to 10 determinations. Fed fish $(\square)$, starved fish $(\boldsymbol{a}) .{ }^{*} P<0.01$; significant differences between groups at each sampling time; different letters express significant differences $(P<0.01)$ within each group throughout the experimental period (one-way analysis of variance followed by Duncan's multiple range-test). 
be essential before plasma samples can be reliably assayed. The presence of IGF-BPs has been demonstrated in trout (Niu \& Le Bail, 1993), channel catfish (Delahunty et al., 1992), coho salmon, striped bass Morone saxatilis Walbaum, tilapia and long-jawed mudsucker (Kelley et al., 1992). The most abundant IGF carrier has a molecular size comparable to that of mammalian IGF-BP3 (50-40 kDa). Thus, following acid gel-exclusion chromatography we detected a false immunoreactive peak in the region of $50 \mathrm{kDa}$, probably due to the presence of IGF-BPs that bind rhIGF-I tracer but are not precipitated by second antibodies in a double antibody-RIA (Nissley \& Rechler, 1985). Mammalian studies support the idea that $50-40 \mathrm{kDa}$ subunits are required to bind IGFs before combining with an acid-labile non-binding subunit to form a $150 \mathrm{kDa}$ complex (Furlanetto, 1980; Baxter, 1986). Whether a protein homologous to an acid-labile subunit exists or not in fish species, requires further research.

The co-ordinate regulation of IGF-I synthesis and GH-binding by fasting is of considerable interest. Previous mammalian studies indicate that the number of liver GH receptors decreases during fasting (Maes et al., 1983). Since GH is a positive regulator of IGF-I synthesis, this decline in GH-binding might explain, at least in part, the GH insensitivity and the decreased synthesis of IGF-I that occurs in the liver during nutritional deprivation. The most persuasive evidence is that the magnitude and kinetics of the decline in GH receptor mRNA are similar to the magnitude and kinetics of the decline in IGF-I mRNA (Straus \& Takemoto, 1990). Unfortunately, the knowledge of the regulation of GH action in fish species is far from that of mammals. Using ${ }^{35} \mathrm{SO}_{4}$ incorporation by ceratobranchial cartilage as an indirect measure of somatomedin activity, it has been suggested that fasting decreases hepatic IGF-I release in trout (Komourdjian \& Idler, 1978), long-jawed mudsucker (Gray \& Kelley, 1991) and coho salmon (McCormick et al., 1992). Moreover, Duan \& Hirano (1992) have reported a significant decrease of hepatic IGF-I mRNA in starved Japanese eel. A significant decrease in free and total hepatic GH-binding has also been demonstrated in coho salmon after 3 weeks of fasting (Gray et al., 1992). Similarly, we observed a temporal relationship between the decrease and increase of hepatic GH-binding and plasma IGF-I-like immunoreactivity during fasting and refeeding of gilthead sea bream. However, a significant effect of fasting and refeeding on plasma IGF-like activity has not been established in tilapia (Drakenberg et al., 1989; T. B. Ng \& T. C. Leung, unpublished results). This apparent discrepancy could reflect a short period of food deprivation or a low somatic growth when food deprivation was imposed. Thus, in our study, the seasonal increase of somatic growth (April-June) could contribute to amplify the difference in plasma IGF-I activity between fed and starved fish. In fed fish, we observed a significant increase of plasma IGF-I-like immunoreactivity in coincidence with a progressive decrease of free GH-binding sites. This decline was accompanied by a significant increase of total GH-binding sites in the last sampling time. This up-regulation of hepatic GH receptors could be due to the increase of plasma GH levels, which precedes the seasonal increase of somatic growth in goldfish (Marchant \& Peter, 1986). In agreement with this idea, Mori and coworkers (1992) have demonstrated that a single injection of $\mathrm{GH}$ up-regulates hepatic GH receptors in Japanese eel. 
In summary, the present paper constitutes the first report which indicates a co-ordinated regulation of GH-binding and plasma IGF activity in a typical marine fish, such as gilthead sea bream.

We are grateful to Ciba-Geigy for supplying rhIGF-I. We are grateful to the National Hormone and Pituitary Distribution Program for providing antisera and mammalian hormones. We also thank Dr B. Breton and Dr J. Smal for supplying the fish hormones.

\section{References}

Baxter, R. C. (1986). Characterization of the acid-labile subunit of the growth hormonedependent insulin-like growth factor binding protein complex. Journal of Clinical Endocrinology and Metabolism 67, 265-272.

Baxter, R. C. (1988). The insulin-like growth factors and their binding proteins. Comparative Biochemistry and Physiology 91B, 229-235.

Cao, Q-P., Duguay, S. J., Plisetskaya, E., Steiner, D. F. \& Chan, S. J. (1989). Nucleotide sequence and growth hormone-regulated expression of salmon insulin-like growth factor I mRNA. Molecular Endocrinology 3, 2005-2010.

Cuatrecasas, P., Hollenberg, M. D., Chang, K. J. \& Bennett, V. (1977). Hormone receptor complexes and their modulation of membrane function. Recent Progress in Hormone Research 31, 37-94.

Daughaday, W. H., Kapadia, M., Yanow, C. E., Fabrick, K. \& Mariz, I. K. (1985). Insulin-like growth factors I and II of nonmammalian sera. General and Comparative Endocrinology 59, 316-325.

Delahunty, G., Jedrick, C. \& Jedlicka, A. (1992). Insulin-like growth factor I and insulin-like growth factor-binding protein in the channel catfish (Ictalurus punctatus). Abstracts of the 2nd International Symposium on Fish Endocrinology, $\mathrm{L}_{58}$, Saint-Malo, France.

Drakenberg, K., Sara, V. R., Lindahl, K. I. \& Kewish, B. (1989). The study of insulin-like growth factors in tilapia, Oreochromis mossambicus. General and Comparative Endocrinology 74, 173-180.

Duan, C. \& Hirano, T. (1990). Stimulation of ${ }^{35}$ S-sulfate uptake by mammalian insulin-like growth factors I and II in cultured cartilages of the Japanese eel, Anguilla japonica. Journal of Experimental Zoology 256, 347-350.

Duan, C. \& Hirano, T. (1992). Effects of insulin-like growth factor-I and insulin on the in-vitro uptake of sulfate by eel branchial cartilage: evidence for the presence of independent hepatic and pancreatic sulphation factors. Journal of Endocrinology 133, 211-219.

Duan, C. \& Inui, Y. (1990). Effects of recombinant eel growth hormone on the uptake of ${ }^{35} \mathrm{~S}$-sulfate by ceratobranchial cartilages of the Japanese eel, Anguilla japonica. General and Comparative Endocrinology 79, 320-325.

Fryer, J. N. (1979). A radioreceptor assay for purified teleost growth hormone. General and Comparative Endocrinology 39, 123-130.

Funkenstein, B., Silbergeld, A., Cavari, B. \& Laron, Z. (1989). Growth hormone increases plasma levels of insulin-like growth factor (IGF-I) in a teleost, the gilthead sea bream (Sparus aurata). Journal of Endocrinology 120, R19-R21.

Furlanetto, R. W. (1980). The somatomedin C binding protein: evidence for a heterologous subunit structure. Journal of Clinical Endocrinology and Metabolism 51, $12-19$.

Furlanetto, R. W., Underwood, L. E., Van Wyk, J. J. \& D'Ercole, A. J. (1977). Estimation of somatomedin-C levels in normals and patients with pituitary disease by radioimmunoassay. Journal of Clinical Investigation 60, 648-657.

Gerasimo, P., Dyiane, P. \& Kelly, P. A. (1979). Titration of total binding sites for growth hormone in rabbit liver. Quantitative modification of these sites during pregnancy. Molecular and Cellular Endocrinology 13, 11-23. 
Gray, E. S. \& Kelley, K. M. (1991). Growth regulation in the gobiid teleost, Gillichthys mirabilis: roles of growth hormone, hepatic growth hormone receptors and insulin-like growth factor-I. Journal of Endocrinology 131, 57-66.

Gray, E. S., Kelley, K. M., Law, S., Tsai, R., Young, G. \& Bern, H. A. (1992). Regulation of hepatic growth hormone receptors in coho salmon (Oncorhynchus kisutch). General and Comparative Endocrinology 88, 243-252.

Gray, E. S., Young, G. \& Bern, H. (1990). Radioreceptor assay for growth hormone in coho salmon (Oncorhynchus kisutch) and its application to the study of stunting. Journal of Experimental Zoology 256, 290-296.

Greenwood, F. C., Hunter, W. M. \& Glover, J. S. (1963). The preparation of ${ }^{131}$ I-labelled human $\mathrm{GH}$ of high specific radioactivity. Biochemical Journal 89, $114-123$.

Hirano, T. (1991). Hepatic receptor for homologous growth hormone in eel (Anguilla japonica). General and Comparative Endocrinology 81, 383-390.

Holly, J. M. P. \& Wass, J. A. H. (1989). Insulin-like growth factors; autocrine, paracrine or endocrine? New perspectives of the somatomedin hypothesis in the light of recent developments. Journal of Endocrinology 122, 611-618.

Hughes, J. P. (1979). Identification and characterization of high and low affinity binding sites from growth hormone in rabbit liver. Endocrinology 105, 414-420.

Kelley, K. M., Siharath, K. \& Bern, H. A. (1992). Identification of insulin-like growth factor-binding proteins in the circulation of four teleost fish species. Journal of Experimental Zoology 263, 220-224.

Kelley, P. A., Leblanc, G. \& Djiane, J. (1979). Estimation of total prolactin binding sites after in vitro desaturation. Endocrinology 104, 1631-1638.

Komourdjian, M. P. \& Idler, D. R. (1978). Hepatic mediation of hormonal and nutritional factors influencing the in vitro sulfur uptake by rainbow trout bone. General and Comparative Endocrinology 36, 33-39.

Le Bail, P-Y., Boulard, G., Barrenton, B. \& Zygmunt, M. (1989). Purification of chinook salmon (Oncorhynchus tshawytscha) GH for receptor study. Fish Physiology and Biochemistry 7, 243-251.

Le Bail, P-Y., Mourot, B., Zohar, Y. \& Pérez-Sánchez, J. (1993). Application of a sensitive radioimmunoassay for the measurement of growth hormone $(\mathrm{GH})$ in gilthead sea bream (Sparus aurata) and other sparid fishes. Canadian Journal of Zoology in press.

Leung, F. C., Style, N. Y., Rosenblum, C. I., Lilburn, M. S. \& Marsh, J. A. (1987). Diminished hepatic growth hormone receptor binding in sex-linked dwarf broiler and leghorn chicken. Proceedings of the Society for Experimental Biology and Medicine 184, 234-238.

Li, C. H. (1972). Recent knowledge of the chemistry of lactogenic hormones. In Lactogenic Hormones (Wolstenholme, G. E. W. \& Knight, J., eds), pp. 7-26. London: Churchill Livingstone.

Lindahl, K. L., Sara, V. R., Fridberg, G. \& Nishimiya, T. (1985). The presence of somatomedin in the Baltic salmon, Salmo salar, with special reference to smoltification. Aquaculture 45, 177-183.

Maes, M., Underwood, L. E. \& Ketelslegers, J. M. (1983). Plasma somatomedin-C in fasted and refed rats: close relationship with changes in liver somatogenic but not lactogenic binding sites. Journal of Endocrinology 97, 243-252.

Maiter, D., Underwood, L. E., Maes, M. \& Ketelslegers, J. M. (1988). Acute downregulation of the somatogenic receptors in rat liver by a single injection of growth hormone. Endocrinology 122, 1291-1296.

Marchant, T. A. \& Peter, R. E. (1986). Seasonal variations in body growth rates and circulating levels of growth hormone in the goldfish, Carassius auratus. Journal of Experimental Zoology 237, 231-239.

Martal, J. (1972). Determination radioimmunologique des hormones de croissance ovine et obine: étude des conditions d'iodation et obtention d'une hormone somatotrope radiodée sans prolactine contaminante. Comptes Rendues à l'Academie des Sciences de Paris 274, 2893-2896. 
McCormick, S. D., Tsai, P. I., Kelley, K. M., Nishioka, R. S. \& Bern, H. A. (1992). Hormonal control of sulfate uptake by branchial cartilage of coho salmon: role of IGF-I. Journal of Experimental Zoology 262, 166-171.

Mendelshon, L. G. (1988). Minireview: growth hormone receptors. Life Sciences 43, $1-5$.

Mori, I., Sakamoto, T. \& Hirano, T. (1992). Growth hormone (GH)-dependent hepatic GH receptors in the Japanese eel, Anguilla japonica. Effects of hypophysectomy and GH injection. General and Comparative Endocrinology 85, 385-391.

Ng, T. B., Leung, T. C., Cheng, C. H. K. \& Wood, Y. S. (1992). Growth hormone binding in tilapia (Oreochromis mossambicus) liver. General and Comparative Endocrinology 86, 111-118.

Ng, T. B., Leung, T. C. \& Woo, Y. S. (1991). Insulin-like growth factor I-like immunoreactivity in serum and tissues of the tilapia, Oreochromis mossambicus. Biochemistry International 24, 359-368.

Nissley, S. P. \& Rechler, M. M. (1985). Insulin-like growth factors: Biosynthesis, receptors and carrier proteins. In Hormonal Proteins and Peptides (Li, C. H., ed.), pp. 127-203. London: Academic Press.

Niu, P. D. \& Le Bail, P-Y. (1993). Presence of insulin-like growthfactor binding protein (IGF-BP) in rainbow trout (Oncorhynchus mykiss) serum. Journal of Experimental Zoology 265, 627-636.

Niu, P. D., Pérez-Sánchez, J. \& Le Bail, P-Y. (1993). Development of a protein binding assay for teleost insulin-like growth factor (IGF)-like: relationship between growth hormone $(\mathrm{GH})$ and IGF-like in the blood of rainbow trout (Oncorhynchus mykiss). Fish Physiology and Biochemistry 11, 381-391.

Pérez-Sánchez, J., Weil, C. \& Le Bail, P.Y. (1992). Effects of human insulin-like growth factor-I on release of growth hormone by rainbow trout (Oncorhynchus mykiss) pituitary cells. Journal of Experimental Zoology 262, 287-290.

Sakamoto, T. \& Hirano, T. (1991). Growth hormone receptors in the liver and osmoregulatory organs of rainbow trout: characterization and dynamics during adaptation to sea water. Journal of Endocrinology 130, 425-433.

Salmon, W. D. \& Daughaday, W. H. (1957). A hormonally controlled serum factor which stimulates sulfate incorporation by cartilage in vitro. Journal of Laboratory and Clinical Medicine 49, 825-836.

Straus, D. S. \& Takemoto, C. D. (1990). Effect of fasting on insulin-like growth factor-I (IGF-I) and growth hormone receptor mRNA levels and IGF-I gene transcription in rat liver. Molecular Endocrinology 4, 91-100.

Tarpey, J. F. \& Nicoll, C. S. (1985). Characterization of hepatic growth hormone binding sites in two fish species, Gillichthys mirabilis (Teleostei) and Acipenser transmontanus (Chondrostei). General and Comparative Endocrinology 60, 39-50.

Wilson, D. M. \& Hintz, R. L. (1982). Inter-species comparison of somatomedin structure using immunological probes. Journal of Endocrinology 95, 59-64.

Yao, K., Niu, P. D., Le Gac, F. \& Le Bail, P-Y. (1991). Presence of GH specific binding sites in rainbow trout (Oncorhynchus mykiss) tissues: characterization of the hepatic receptor. General and Comparative Endocrinology 81, 72-82.

Zapf, J., Morell, B., Walter, H., Laron, Z. \& Froesch, E. R. (1980). Serum levels of insulin-like growth factor (IGF) and its carrier protein in various metabolic disorders. Acta Endocrinologica 95, 505-516. 